\title{
Some New Hydrazone Derivatives Bearing the 1,2,4-Triazole Moiety as Potential Antimycobacterial Agents
}

\section{Antimikobakteriyel Etki Göstermesi Beklenen Yeni Bazı 1,2,4-Triazol Yapısı Taşıyan Hidrazon Türevleri}

\author{
(D) Keriman ÖZADALI SARI ${ }^{1}$, (D) Oya ÜNSAL TAN ${ }^{*}$, (D) Dharmarajan SRIRAM², (D) Ayla BALKAN1 \\ ${ }^{1}$ Hacettepe University, Faculty of Pharmacy, Department of Pharmaceutical Chemistry, Ankara, Turkey \\ 2Birla Institute of Technology and Science - Pilani, Pharmacy Group, Medicinal Chemistry and Antimycobacterial Research Laboratory, Hyderabad \\ Campus, Jawahar Nagar, Hyderabad, Andhra Pradesh, India
}

\section{ABSTRACT}

Objectives: The aim of this study was to synthesize, characterize, and screen some new 1-(4-((2-(4-substitutedphenyl)hydrazono)methyl)phenyl)$1 \mathrm{H}-1,2,4$-triazole derivatives for their antimycobacterial activities.

Materials and Methods: The target compounds (2a-h) were gained by condensation of 4-(1H-1,2,4-triazol-1-yl)benzaldehyde with appropriate phenylhydrazines. Their structures were elucidated by IR, ${ }^{1} \mathrm{H}-\mathrm{NMR}$, and mass spectrometry. The antimycobacterial activities of the compounds were determined in vitro against Mycobacterium tuberculosis H37Rv.

Results: The biological assay results showed that the methylsulfonyl-substituted derivative $2 \mathrm{f}$ displayed the highest antimycobacterial activity in this series.

Conclusion: Although the methylsulfonyl-substituted derivative exhibited significant antimycobacterial activity, none of the synthesized compounds was as effective as isoniazid, rifampin, ethambutol, and ciprofloxacin against M. tuberculosis.

Key words: Hydrazone, 1,2,4-triazole, antimycobacterial activity

\section{ÖZ}

Amaç: Bu çalışma, 1-(4-((2-(4-sübstitüefenil)hidrazono)metil)fenil)-1H-1,2,4-triazol türevlerinin sentezlerini yaparak yapılarını aydınlatmayı ve antimikobakteriyel aktivitelerini incelemeyi amaçlamaktadır.

Gereç ve Yöntemler: Bu çalışmada hedef bileşikler (2a-h), 4-(1H-1,2,4-triazol-l-il)benzaldehidin uygun fenilhidrazinlerle kondenzasyonu ile elde edilmiștir. Bileșiklerin yapıları, IR, 1H-NMR ve kütle spektrometrisi ile aydınlatılmıștır. Antimikobakteriyel aktiviteleri, Mycobacterium tuberculosis H37Rv'ye karșı in vitro olarak incelenmiştir.

Bulgular: Aktivite sonuçları incelendiğinde, metilsülfonil sübstitüe türevin $2 f$ serinin en aktif üyesi olduğu bulunmuştur.

Sonuç: Metilsulfonil sübstitüe türevin dikkate değer antimikobakteriyel aktivite göstermesine rağmen, sentezlenen bileşiklerin hiçbirinin $M$. tuberculosis'e karşı izoniazit, rifampin, etambutol ve siprofloksazin kadar etkili olmadıkları bulunmuştur.

Anahtar kelimeler: Hidrazon, 1,2,4-triazol, antimikobakteriyel aktivite 


\section{INTRODUCTION}

Tuberculosis (TB), caused by Mycobacterium tuberculosis, is the ninth leading cause of death worldwide and the leading cause from a single infectious agent. In 2016, there were an estimated 10.4 million newly infected persons with 600,000 of the cases resistant to rifampicin (RIF), the most effective first-line drug, of which 490,000 had multidrug-resistant TB (MDR-TB). MDR-TB is characterized by resistance to at least the two most powerful first-line anti-TB drugs, isoniazid and RIF. Moreover, extensively drug-resistant TB (XDR-TB), defined as additional resistance to at least one fluoroquinolone and one second-line injectable drug (amikacin, kanamycin), is spreading rapidly all over the world.' The World Health Organization declared an urgent need to develop new drugs and strategies for efficient treatment because of the increasing resistance of M. tuberculosis strains. ${ }^{2}$

RIF, isoniazid, ethambutol (EMB), and pyrazinamide have been used as first-line drugs for TB chemotherapy for more than 50 years. ${ }^{3,4}$ Second-line and third-line drugs, which are expensive, less effective, and more toxic than the first-line antiTB drugs, are administered in combination for the treatment of MDR-TB.5.6 Treatment approaches for MDR-TB have shown that increasing the number of medications used is more successful than increasing the duration of treatment. ${ }^{7-9}$ Current treatment regimens have not been able to reduce the number of MDRTB and XDR-TB infections while achieving reductions in the number of TB infections and death. Despite all this knowledge and notable efforts, only two new anti-TB drugs, bedaquiline and delamanid, were approved for TB therapy in the last halfcentury. ${ }^{10-12}$ However, the adaptation of $M$. tuberculosis has already led to the emergence of resistant strains for these drugs. For this reason, more chemotherapeutic agents are still needed.13

Azole antifungal/antimycobacterial drugs, containing one of the most important classes of heterocycles, such as econazole, miconazole, and clotrimazole, stop the growth of bacteria by inhibiting P450 enzymes (CYP51, CYP121, and CYP130) and show inhibitory potential against MDR-TB in vitro and in vivo (infected mice). ${ }^{14-16}$ It was also shown that some azole derivatives display a mixed-function oxidase on sterol synthesis in eukaryotic organisms. ${ }^{17}$

Hydrazones possessing an azometine $-\mathrm{NHN}=\mathrm{CH}$ - moiety have been extensively investigated for their potential as anti-TB drug candidates as well as for other biological and pharmacological

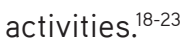

In the light of above-mentioned considerations, we designed and synthesized new hydrazone compounds carrying a 1,2,4-triazole ring in order to investigate of their antimycobacterial activity against M. tuberculosis.

\section{MATERIALS AND METHODS}

\section{Chemistry}

Melting points were determined with a Thomas-Hoover Capillary Melting Point Apparatus and are uncorrected.
Attenuated total reflection-fourier transform infrared (ATRFTIR) spectra were obtained using the MIRacle ATR accessory (Pike technologies) in conjunction with a Spectrum BX FTIR spectrometer (PerkinElmer) and are reported in $\mathrm{cm}^{-1}$. The ${ }^{1} \mathrm{H}-\mathrm{NMR}(400 \mathrm{MHz})$ spectra (DMSO- $\mathrm{d}_{6}$ ) were recorded on a Varian Mercury 400 FT NMR spectrometer using TMS as an internal reference (chemical shift represented in $\delta \mathrm{ppm}$ ). The electrospray-ionization-mass spectrometry (ESI-MS) spectra were measured on a Micromass ZQ-4000 single quadruple mass spectrometer.

Synthesis of 1-(4-((2-(4-substitutedphenyl)hydrazono)methyl) phenyl)-1H-1,2,4-triazole derivatives (2a- $h$ )

Equimolar amounts of 4-(1H-1,2,4-triazol-1-yl)benzaldehyde (1) and an appropriate phenylhydrazine derivative were refluxed in ethanol in the presence of acetic acid (1-2 drops) as a catalytic reagent for $4 \mathrm{~h}$. The solid precipitate was filtered and crystallized from acetonitrile.

1-(4-((2-phenylhydrazono)methyl)phenyl)-1H-1,2,4-triazole (2a)

Yield 44\% (white solid). Mp 184-187 ${ }^{\circ} \mathrm{C}$. IR (ATR, $\mathrm{cm}^{-1}$ ); 3232, 3124, 3038, 1603, 1591, 1563, 1517, 1494, 1266. 'H-NMR (DMSO-d ' $^{\prime}$ ppm); $\delta 10.45(1 \mathrm{H}$; br; $-\mathrm{NH}-), 9.27(1 \mathrm{H}$; s; triazole), $8.22(1 \mathrm{H} ; \mathrm{s}$; triazole), $7.85(2 \mathrm{H}$; d; ar. J: $8.8 \mathrm{~Hz}), 7.84(1 \mathrm{H}$; s; $-\mathrm{N}=\mathrm{CH}-), 7.78$ $(2 \mathrm{H}$; d; ar. J: $8.8 \mathrm{~Hz}), 7.20(2 \mathrm{H}$; t; ar. J: $7.6 \mathrm{~Hz}), 7.06(1 \mathrm{H}$; d; ar. J: $7.8 \mathrm{~Hz}), 6.74(2 \mathrm{H} ; \mathrm{t} ;$ ar. $)$. ESI-MS (m/z); $286[\mathrm{M}+\mathrm{Na}]^{+}, 264[\mathrm{M}+\mathrm{H}]^{+}$. Anal. Calcd. for $\mathrm{C}_{15} \mathrm{H}_{13} \mathrm{~N}_{5}$ : C, 68.43; $\mathrm{H}, 4.98 ; \mathrm{N}, 26.60$. Found: C, 68.71; H, 4.57; N, 26.77.

\section{1-(4-((2-(4-methoxyphenyl)hydrazono)methyl)phenyl)-1H-} 1,2,4-triazole (2b)

Yield $42 \%$ (white solid). Mp $212-216^{\circ} \mathrm{C}$. IR (ATR, $\mathrm{cm}^{-1}$ ); 3174, $3112,3020,1608,1540,1503,1223,1137 .{ }^{1} H-N M R$ (DMSO-d , $^{\prime}$ $400 \mathrm{MHz}, \mathrm{ppm}) ; \delta 9.33(1 \mathrm{H}$; s; triazole), $8.24(1 \mathrm{H} ; \mathrm{s}$; triazole), 7.84-7.82 (3H; $\mathrm{m}$; ar. and $-\mathrm{N}=\mathrm{CH}-), 7.74(2 \mathrm{H}$; d; ar. J: $8.8 \mathrm{~Hz})$, $7.01(2 \mathrm{H}$; d; ar. J: $8.8 \mathrm{~Hz}), 6.81(2 \mathrm{H}$; d; ar. J: $8.8 \mathrm{~Hz}), 3.79(3 \mathrm{H}$; s; $-\mathrm{OCH}_{3}$ ). ESI-MS (m/z); $316[\mathrm{M}+\mathrm{Na}]^{+}, 294[\mathrm{M}+\mathrm{H}]^{+}$. Anal. Calcd. for $\mathrm{C}_{16} \mathrm{H}_{15} \mathrm{~N}_{5} \mathrm{O}: \mathrm{C}, 65.52 ; \mathrm{H}, 5.15 ; \mathrm{N}, 23.88$. Found: $\mathrm{C}, 65.65 ; \mathrm{H}, 5.43$; $\mathrm{N}, 23.64$.

1-(4-((2-(4-carboxyphenyl)hydrazono )methyl)phenyl)-1H1,2,4-triazole (2c)

Yield $41 \%$ (white solid). Mp $>265^{\circ} \mathrm{C}$. IR (ATR, $\mathrm{cm}^{-1}$ ); 3418, 3255, 3049, 1680, 1649, 1598, 1519, 1264. ${ }^{1} \mathrm{H}-\mathrm{NMR}$ (DMSO-d 6 , 400 $\mathrm{MHz}, \mathrm{ppm}) ; \delta 12.29(1 \mathrm{H} ; \mathrm{br} ; \mathrm{COOH}), 10.90(1 \mathrm{H} ; \mathrm{br} ;-\mathrm{NH}-), 9.31$ $(1 \mathrm{H}$; s; triazole), $8.22(1 \mathrm{H}$; s; triazole), $7.96(1 \mathrm{H} ; \mathrm{s} ;-\mathrm{N}=\mathrm{CH}-), 7.88-$ $7.79(6 \mathrm{H}$; m; ar.), $7.11(2 \mathrm{H}$; d; ar.; J: $8.8 \mathrm{~Hz})$. ESI-MS (m/z); 330 $[\mathrm{M}+\mathrm{Na}]^{+}, 308[\mathrm{M}+\mathrm{H}]^{+}$. Anal. Calcd. for $\mathrm{C}_{16} \mathrm{H}_{13} \mathrm{~N}_{5} \mathrm{O}_{2}: \mathrm{C}, 62.53 ; \mathrm{H}$, 4.26; N, 22.79. Found: C, 62.90; H, 4.38; N, 23.06.

1-(4-((2-(4-cyanophenyl)hydrazono)methyl)phenyl)-1H-1,2,4triazole (2d)

Yield $71 \%$ (white solid). Mp $>265^{\circ} \mathrm{C}$. IR (ATR, cm${ }^{-1}$ ); 3232, 3112, 3036, 2209, 1610, 1599, 1572, 1521, 1503, 1276. ' ${ }^{1 H}$-NMR (DMSO-d $, 400 \mathrm{MHz}, \mathrm{ppm}) ; \delta 11.11(1 \mathrm{H}$; br; $-\mathrm{NH}-), 9.35(1 \mathrm{H}$; s; triazole), $8.25(1 \mathrm{H}$; s; triazole), $8.01(1 \mathrm{H} ; \mathrm{s} ;-\mathrm{N}=\mathrm{CH}-), 7.92-7.85$ (4H; m; ar.), $7.62(2 \mathrm{H}$; d; ar. J: $9.2 \mathrm{~Hz}), 7.18(2 \mathrm{H}$; d; ar. J: $8.4 \mathrm{~Hz})$. 
ESI-MS (m/z); $311[\mathrm{M}+\mathrm{Na}]^{+}, 289[\mathrm{M}+\mathrm{H}]^{+}$. Anal. Calcd. for $\mathrm{C}_{16} \mathrm{H}_{12} \mathrm{~N}_{6}$ : C, 66.66; H, 4.20; N, 29.15. Found: C, 67.00; H, 4.61; N, 29.23.

1-(4-((2-(4-sulfamoylphenyl)hydrazono)methyl)phenyl)-1H1,2,4-triazole (2e)

Yield $76 \%$ (white solid). Mp $>265^{\circ} \mathrm{C}$. IR (ATR, $\mathrm{cm}^{-1}$ ); 3359, 3272, 3130, 1591, 1572, 1515, 1308, 1132, 1094. 'H-NMR (DMSO-d , 400 $\mathrm{MHz}, \mathrm{ppm}) ; \delta 10.96(1 \mathrm{H} ; \mathrm{br} ;-\mathrm{NH}-), 9.34(1 \mathrm{H}$; s; triazole), 8.24 $(1 \mathrm{H}$; s; triazole), $7.98(1 \mathrm{H} ; \mathrm{s} ;-\mathrm{N}=\mathrm{CH}-), 7.89-7.83$ (4H; m; ar.), 7.65 $(2 \mathrm{H}$; d; ar. J: $8.8 \mathrm{~Hz}), 7.16(2 \mathrm{H}$; d; ar. J: $8.8 \mathrm{~Hz}), 7.05(2 \mathrm{H}$; br; $\left.-\mathrm{NH}_{2}\right)$. ESI-MS (m/z); $365[\mathrm{M}+\mathrm{Na}]^{+}, 343[\mathrm{M}+\mathrm{H}]^{+}$. Anal. Calcd. for $\mathrm{C}_{15} \mathrm{H}_{14} \mathrm{~N}_{6} \mathrm{O}_{2} \mathrm{~S}$ : C, 52.62; $\mathrm{H}, 4.12 ; \mathrm{N}, 24.55$. Found: C, 52.89; $\mathrm{H}, 4.47$; $\mathrm{N}, 24.83$.

1-(4-((2-(4-(methylsulfonyl)phenyl)hydrazono)methyl) phenyl)-1H-1,2,4-triazole (2f)

Yield $77 \%$ (white solid). Mp $>265^{\circ} \mathrm{C}$. IR (ATR, cm ${ }^{-1}$ ); 3269, 3134, 3082, 1591, 1572, 1518, 1263, 1124, 1087. 'H-NMR (DMSO-d, 400 $\mathrm{MHz}, \mathrm{ppm}) ; \delta 11.03$ (1H; br; -NH-), $9.32(1 \mathrm{H}$; s; triazole), $8.23(1 \mathrm{H}$; s; triazole), $7.99(1 \mathrm{H} ; \mathrm{s} ;-\mathrm{N}=\mathrm{CH}-), 7.90-7.84(4 \mathrm{H} ; \mathrm{m}$; ar. $), 7.72(2 \mathrm{H}$; d; ar. J: $8.4 \mathrm{~Hz}), 7.21(2 \mathrm{H}$; d; ar. J: $8.8 \mathrm{~Hz}), 3.09\left(3 \mathrm{H}\right.$; s; $\left.\mathrm{CH}_{3}\right)$. ESI$\mathrm{MS}(\mathrm{m} / \mathrm{z}) ; 364[\mathrm{M}+\mathrm{Na}]^{+}, 342[\mathrm{M}+\mathrm{H}]^{+}$. Anal. Calcd. for $\mathrm{C}_{16} \mathrm{H}_{15} \mathrm{~N}_{5} \mathrm{O} 2 \mathrm{~S}$ : C, 56.29; H, 4.43; N, 20.51. Found: C, 56.08; H, 4.68; N, 20.87.

1-(4-((2-(4-nitrophenyl)hydrazono)methyl)phenyl)-1H-1,2,4triazole (2g)

Yield 59\% (white solid). Mp $>265^{\circ} \mathrm{C}$. IR (ATR, cm${ }^{-1}$ ); 3191, 3126, 3038, 1609, 1592, 1521, 1306, 1274, 1109. 'H-NMR (DMSO-d 400 $\mathrm{MHz}, \mathrm{ppm}) ; \delta 11.37(1 \mathrm{H} ; \mathrm{br}$; $-\mathrm{NH}-), 9.33(1 \mathrm{H}$; s; triazole), $8.23(1 \mathrm{H}$; s; triazole), $8.11(2 \mathrm{H}$; d; ar. J: $9.6 \mathrm{~Hz}), 8.06(1 \mathrm{H}$; s; $-\mathrm{N}=\mathrm{CH}-), 7.92-$ 7.87 (4H; m; ar.), 7.18 (2H; d; ar. J: 8.4 Hz). ESI-MS (m/z); 331 $[\mathrm{M}+\mathrm{Na}]^{+}, 309[\mathrm{M}+\mathrm{H}]^{+}$. Anal. Calcd. for $\mathrm{C}_{15} \mathrm{H}_{12} \mathrm{~N}_{6} \mathrm{O}_{2}: \mathrm{C}, 58.44 ; \mathrm{H}$, 3.92; N, 27.26. Found: C, 58.76; H, 4.01; N, 27.33.

1-(4-((2-(2,4-dinitrophenyl)hydrazono)methyl)phenyl)-1H1,2,4-triazole ( $2 \mathrm{~h}$ )

Yield 68\% (white solid). Mp $>265^{\circ} \mathrm{C}$. IR (ATR, cm'); 3286, 3097, 1608, 1583, 1497, 1321, 1270, 1134, 1085. ' H-NMR (DMSO-d, 400 $\mathrm{MHz}, \mathrm{ppm}) ; 11.69(1 \mathrm{H}$; br; -NH-), $9.37(1 \mathrm{H} ; \mathrm{s}$; triazole), $8.84(1 \mathrm{H}$; d; ar. J: $2.4 \mathrm{~Hz}), 8.72(1 \mathrm{H} ; \mathrm{s} ;-\mathrm{N}=\mathrm{CH}-), 8.35(1 \mathrm{H}$; dd; ar. J: 2.8 $J_{2}$ : $\left.9.8 \mathrm{~Hz}\right), 8.26(1 \mathrm{H}$; s; triazole), $8.11(1 \mathrm{H}$; d; ar. J: $10 \mathrm{~Hz}), 7.98-$ 7.93 (4H; m; ar.). ESI-MS (m/z); $376[\mathrm{M}+\mathrm{Na}]^{+}, 354[\mathrm{M}+\mathrm{H}]^{+}$. Anal. Calcd. for $\mathrm{C}_{15} \mathrm{H}_{11} \mathrm{~N}_{7} \mathrm{O}_{4}$ : C, 51.00; $\mathrm{H}, 3.14 ; \mathrm{N}, 27.75$. Found: C, 51.36; H, 3.46; N, 28.02.

\section{Antimycobacterial activity assay}

In vitro antimycobacterial activity assays of the synthesized compounds were carried out using the microplate Alamar blue assay method against $M$. tuberculosis H37Rv in duplicate. ${ }^{24}$ Ciprofloxacin, isoniazid, EMB, and rifampin were used as reference compounds. The stock solutions of the compounds were prepared in DMSO. Sterile deionized water $(200 \mu \mathrm{L})$ was added to all outer-perimeter wells of sterile 96-well plates to minimize evaporation of the medium in the test wells during incubation. The wells received $100 \mu \mathrm{L}$ of Middlebrook $7 \mathrm{H} 9 \mathrm{GC}$ broth and two-fold serial dilutions of the target compounds/ positive controls were prepared in a volume of $100 \mu \mathrm{L}$ directly on the plate to get final concentrations of $25,12.5,6.25,3.13,1.56$, and $0.78 \mu \mathrm{g} / \mathrm{mL}$. The inoculum was adjusted to a McFarland tube No. 1 and diluted 1:20. Then $100 \mu \mathrm{L}$ of M. tuberculosis inoculum was added to the wells. The plates were incubated at $37^{\circ} \mathrm{C}$ for 5 days. Next, $50 \mu \mathrm{L}$ of a freshly prepared 1:1 mixture of Alamar Blue (Accumed International, Westlake, Ohio) reagent and $10 \%$ Tween 80 was added to the plates, followed by incubation at $37^{\circ} \mathrm{C}$ for $24 \mathrm{~h}$. A blue color in the well was interpreted as no growth, and a pink color was scored as growth. The MIC was determined as the lowest drug concentration that prevented a color change from blue to pink. MICs of the compounds are reported in Table 1.

\section{RESULTS}

The starting compound, 4-(1H-1,2,4-triazol-1-yl)benzaldehyde (1), was synthesized by the method described in the literature. ${ }^{25}$ The target compounds ( $2 a-h)$ were obtained by condensation of 4-(1H-1,2,4-triazol-1-yl)benzaldehyde with appropriate phenylhydrazines in ethanol in the presence of acetic acid (Scheme 1).

The structures of the target compounds were characterized using spectral methods (IR, ${ }^{1} \mathrm{H}-\mathrm{NMR}$, and ESI-MS). The bands at around 1610 and $3200 \mathrm{~cm}^{-1}$ in the IR spectra of the compounds (2a-h) were evidence of the presence of a hydrazone moiety. In the ${ }^{1} \mathrm{H}-\mathrm{NMR}$ spectra of $2 \mathrm{a}-\mathrm{h}$, the signals belonging to imine and $\mathrm{N}-\mathrm{H}$ protons were observed at around 8.00 and 11.30 ppm, respectively. Moreover, signals were seen at 12.29, 7.05, 3.79, and $3.09 \mathrm{ppm}$ according to substituted moieties $(\mathrm{COOH}$, $\mathrm{SO}_{2} \mathrm{NH}_{2}, \mathrm{OCH}_{3}$, and $\mathrm{SO}_{2} \mathrm{CH}_{3}$, respectively) in the ${ }^{1} \mathrm{H}-\mathrm{NMR}$ spectra. Additionally, the structures of all the target compounds were confirmed by the peaks belonging to $[\mathrm{M}+\mathrm{Na}]^{+}$and $[\mathrm{M}+\mathrm{H}]^{+}$ seen in the ESI mass spectra.

The target compounds $2 \mathrm{a}-\mathrm{h}$ were evaluated for their antimycobacterial activity in vitro against $M$. tuberculosis H37Rv using the microplate Alamar blue assay method. The results of the antimycobacterial activity (MIC values) are

Table 1. Antimycobacterial activities of the compounds

\begin{tabular}{lll} 
Compound & $\mathrm{R}$ & $\mathrm{MIC}$ in $\mu \mathrm{M}$ \\
\hline $2 \mathrm{a}$ & $\mathrm{H}$ & 190.11 \\
\hline $2 \mathrm{~b}$ & $\mathrm{OCH}_{3}$ & 85.32 \\
\hline $2 \mathrm{c}$ & $\mathrm{COOH}$ & $>162.87$ \\
\hline $2 \mathrm{~d}$ & $\mathrm{CN}$ & 173.61 \\
\hline $2 \mathrm{e}$ & $\mathrm{SO}_{2} \mathrm{NH}_{2}$ & 146.20 \\
\hline $2 \mathrm{f}$ & $\mathrm{SO}_{2} \mathrm{CH}_{3}$ & 73.31 \\
\hline $2 \mathrm{~g}$ & $\mathrm{NO}_{2}$ & $>162.34$ \\
\hline $2 \mathrm{~h}$ & $2,4-\mathrm{diNO}_{2}$ & $>141.64$ \\
\hline INH & - & 0.36 \\
\hline Rifampin & - & 0.12 \\
\hline Ethambutol & - & 7.65 \\
\hline Ciprofloxacin & - & 4.71 \\
\hline
\end{tabular}




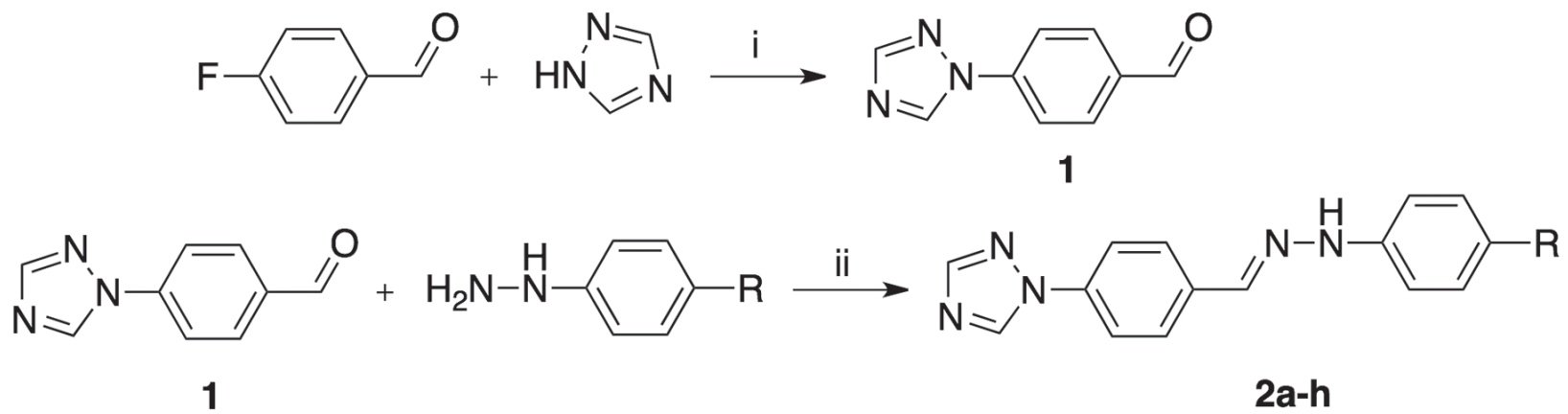

Scheme 1. Synthetic route of the compounds. Reagents and conditions: (i) $\mathrm{K}_{2} \mathrm{CO}_{3}, \mathrm{DMSO}$, ultrasonic irradiation, (ii) $\mathrm{CH}_{3} \mathrm{COOH}_{\text {cat' }}, \mathrm{MeOH}$, reflux

reported in Table 1. As can be seen, the best antimycobacterial activity was obtained by compound $2 f(\mathrm{MIC}=73.31 \mu \mathrm{M})$ in the series. $2 f$ possessed a methylsulfonyl group that is an electron acceptor moiety connected to the phenyl ring. However, the introduction of electron acceptor groups $(\mathrm{COOH}$, $\mathrm{CN}, \mathrm{NO}_{2}$ ) other than methylsulfonyl moiety to the phenyl ring deteriorated antimycobacterial activity. Furthermore, replacing the methylsulfonyl moiety with sulfamoyl reduced the antimycobacterial activity of $2 \mathrm{e}(\mathrm{MIC}=146.20 \mu \mathrm{M})$. In the case of nitro-substituted compounds $(2 \mathrm{~g}$ and $2 \mathrm{~h}$ ), increasing the number of nitro groups on the phenyl ring did not improve the antimycobacterial activity. It was interesting that methoxysubstituted compound $2 \mathrm{~b}$ showed antimycobacterial activity similar to that of $\mathbf{2 f}$, independent of electronic properties of substituents in the series.

\section{CONCLUSIONS}

In conclusions, a series of 1,2,4-triazole-containing hydrazone compounds were synthesized as potential antimycobacterial agents. The biological assay results showed that the methylsulfonyl-substituted derivative $2 f$ showed the highest antimycobacterial activity in the series. Based on the preliminary results, compound $2 \mathrm{f}$ was considered a lead antimycobacterial compound for further optimization.

Conflict of Interest: No conflict of interest was declared by the authors

\section{REFERENCES}

1. Zhenkun MA, Lienhardt C, Mcllleron H, Nunn AJ, Wang X. Global tuberculosis drug development pipeline: the need and the reality. Lancet. 2010;375:2100-2109.

2. World Health Organization (WHO) - Global Tuberculosis Report 2017. Available at http://www.who.int/tb/publications/global_report/en/

3. Saltini C. Chemotherapy and diagnosis of tuberculosis. Respir Med. 2006;100:2085-2097.

4. Tiberi S, Scardigli A, Centis R, D’Ambrosio L, Muñoz-Torrico M, SalazarLezama MÁ, Spanevello A, Visca D, Zumla A, Migliori GB, Caminero Luna JA. Classifying new anti-tuberculosis drugs: rationale and future perspectives. Int J Infect Dis. 2017;56:181-184.
5. Hoagland DT, Liu J, Lee RB, Lee RE. New agents for the treatment of drug-resistant Mycobacterium tuberculosis. Adv Drug Deliv Rev. 2016;102:55-72.

6. Ahmad S, Mokaddas E. Current status and future trends in the diagnosis and treatment of drug-susceptible and multidrug-resistant tuberculosis. J Infect Public Health. 2014;7:75-91.

7. Franke MF, Becerra MC, Tierney DB, Rich ML, Bonilla C, Bayona J, McLaughlin MM, Mitnick CD. Counting pyrazinamide in regimens for multidrug-resistant tuberculosis. Ann Am Thorac Soc. 2015;12:674-679.

8. Kuaban C, Noeske J, Rieder HL, Aït-Khaled N, Abena Foe JL, Trébucq A. High effectiveness of a 12-month regimen for MDR-TB patients in Cameroon. Int J Tuberc Lung Dis. 2015;19:517-524.

9. Van Deun A, Maug AKJ, Salim MAH, Das PK, Sarker MR, Daru P, Rieder $\mathrm{HL}$. Short, highly effective, and inexpensive standardized treatment of multidrug-resistant tuberculosis. Am J Respir Crit Care Med. 2010;182:684-692.

10. Wallis RS, Maeurer M, Mwaba P, Chakaya J, Rustomjee R, Migliori GB, Marais B, Schito M, Churchyard G, Swaminathan S, Hoelscher M, Zumla A. Tuberculosis-advances in development of new drugs, treatment regimens, host-directed therapies, and biomarkers. Lancet Infect Dis. 2016;16:e34-e46.

11. Jones D. Tuberculosis success. Nat Rev Drug Discov. 2013;12:175-176.

12. Skripconoka V, Danilovits M, Pehme L, Tomson T, Skenders G, Kummik T, Cirule A, Leimane V, Kurve A, Levina K, Geiter LJ, Manissero D, Wells $\mathrm{CD}$. Delamanid improves outcomes and reduces mortality in multidrugresistant tuberculosis. Eur Respir J. 2013;41:1393-1400.

13. Kumar K, Abubakar I. Clinical implications of the global multidrug-resistant tuberculosis epidemic. Clin Med (Northfield II). 2015;15(Supp16):s37-s42.

14. Cochrane JR, White JM, Wille U, Hutton CA. Total synthesis of mycocyclosin. Org Lett. 2012;14:2402-2405.

15. Podust LM, Ouellet $H$, von Kries JP, de Montellano PRO. Interaction of Mycobacterium tuberculosis CYP130 with heterocyclic arylamines. J Biol Chem. 2009;284:25211-25219.

16. Ahmad Z, Sharma S, Khuller GK, Singh P, Faujdar J, Katoch VM. Antimycobacterial activity of econazole against multidrug-resistant strains of Mycobacterium tuberculosis. Int J Antimicrob Agents. 2006;28:543-544.

17. Podust LM, Poulos TL, Waterman MR. Crystal structure of cytochrome P450 14-sterol demethylase (CYP51) from Mycobacterium tuberculosis in complex with azole inhibitors. Proc Natl Acad Sci. 2001;98:3068-3073. 
18. Koçyiğit-Kaymakçioğlu B, Ünsalan S, Küçükgüzel SG, Şener G, Rollas S. HPLC analysis of in vivo metabolites of 4-nitrobenzoic acid [(5-nitro-2-thiopheneyl)methylene]hydrazide in rats. Eur J Drug Metab Pharmacokinet. 2007;32:197-203.

19. Gülerman NN, Oruç EE, Kartal F, Rollas S. In vivo metabolism of 4-fluorobenzoic acid [(5-nitro-2-furanyl) methylene] hydrazide in rats. Eur J Drug Metab Pharmacokinet. 2000;25:103-108.

20. Kaymakçioğlu BK, Aktan Y, Süzen S, Gökhan N, Koyunoğlu $S$, Erol K, Yeșilada A, Rollas S. In vivo metabolism of 2-[1'-phenyl3'-(3-chlorophenyl)-2'-propenylyden]hydraz ino-3-methyl-4(3H)quinazolinone in rats. Eur J Drug Metab Pharmacokinet. 2005;30:255260.

21. Savini L, Chiasserini L, Gaeta A, Pellerano C. Synthesis and antitubercular evaluation of 4-quinolylhydrazones. Bioorg Med Chem. 2002;10:2193-2198.
22. Sonar VN, Crooks PA. Synthesis and antitubercular activity of a series of hydrazone and nitrovinyl analogs derived from heterocyclic aldehydes. J Enzyme Inhib Med Chem. 2009;24:117-124.

23. Ferreira ML, Candea ALP, Henriques MGMO, Kaiser CR, Lima CHS, De Souza MVN. Synthesis and cytotoxic evaluation of disubstituted $\mathrm{N}$-acylhydrazones pyrazinecarbohydrazide derivatives. Lett Drug Des Discov. 2010;7:275-280.

24. Collins LA, Franzblau SG. Microplate alamar blue assay versus BACTEC 460 system for high-throughput screening of compounds against Mycobacterium tuberculosis and Mycobacterium avium. Antimicrob Agents Chemother. 1997;41:1004-1009.

25. Mečiarová M, Toma Š, Magdolen P. Ultrasound effect on the aromatic nucleophilic substitution reactions on some haloarenes. Ultrason Sonochem. 2003;10:265-270. 